\title{
Cooperatives and Development: Lessons from the Punjab Experience
}

\author{
KHALID MUSTAFA and ZULFIQAR AHMAD GILL
}

\section{INTRODUCTION}

Traditionally, cooperatives have been expected to serve a broad set of sociopolitical and economic objectives ranging from self-help and grass-root participation to welfare and distribution, including economies of scale and social control over resource allocation and mobilisation. However, these various objectives are not mutually consistent. There exists substantial trade-off in the realisation of many of these goals. It is therefore necessary to weigh their relative importance in the felt needs and priorities of a particular community at any given point of time if performance of cooperatives is to be evaluated in an appropriate context. An attempt to fulfil a range of these conflicting objectives simultaneously has eventually led to a broad based disenchantment with the cooperative movement.

This paper highlights two sets of issues with respect to cooperative development. First, it discusses the concept of cooperation and illustrates that the contradictions in the ideology and practice are more significant in explaining the limitations of cooperatives to serve as an instrument of development. Second, the paper points out that in the absence of various external and internal prerequisites, especially due to the lack of their recognition, cooperatives tend to be inefficient relative to other forms of traditional institutions even after receiving subsidies and other types of assistance, thus neither achieving efficiency nor development. By analysing the area of agricultural credit, in which cooperatives have traditionally been most active in the Punjab, this paper illustrates various dilemmas and contradictions and the preconditions necessary for credit cooperatives to reach the rural poor effectively. Finally, the paper points out the implications of the past experience for the future role of cooperatives in Punjab.

Khalid Mustafa and Zulfiqar Ahmad Gill are associated with the Faculty of Agricultural Economics and Rural Sociology, University of Agriculture, Faisalabad. 


\section{Conceptual Framework}

The basic principles underlying modern cooperatives developed in Britain and Western Europe during the 19th century. Different conceptions that emerged in the process of evolution of cooperative thinking can be broadly placed in two major categories: the pragmatic and the idealistic. In the first category may be placed the conception that the primary aim of cooperatives is to help improve economic conditions of those who stand to lose if they individually face powerful interests and privileged competitors. Thus cooperation is not an instrument to transform capitalist system and replace it by some contrasting alternative. Instead, its distinctive institutional form is designed to mitigate inequalities and harshness of capitalistic system altering the distribution of its benefits in the process of making it more workable. The idealistic ideologists however conceived of cooperatives as an instrument to effect the transformation of the capitalist system. They held that cooperatives were fundamentally non-capitalistic and could co-exist with capitalism only at the risk of becoming capitalistic themselves. ${ }^{1}$

The pragmatists perceive cooperatives as entirely voluntary organisations formulated with a view to deriving economic benefits for its members through a common enterprise on the basis of two important criteria: mutual cooperation and selfhelp. According to this concept, benefits arising from undertaking a cooperative enterprise are to be distributed in proportion to the contributions made by individual members. Exponents of this view conclude that unlike, European cooperatives, those in developing countries are frequently expected to cope with far too many constraints, and this is one of the main reasons why cooperatives often remain ineffective in benefiting their members. The broader concept of cooperation, on the other hand, acknowledges the inter-action between economic and socio-political power and, therefore, recognises the frequent need either for structural change or for political mobilisation for cooperatives to be able to benefit their members, especially the poor. ${ }^{2}$

\section{EVOLUTION OF COOPERATIVES IN PUNJAB}

Debt-peonage and chronic credit shortage were among the chief causes of low agricultural incomes and productivity in the Indian sub-continent, in the later half of the last century. The British administration in the sub-continent set up various commissions of inquiry. Among recommendations made by these commissions was the proposal that the government enter the business of credit supply through the introduction of cooperative credit societies. As a result, a cooperative credit societies Act was passed in 1904 and was supplemented by another Act in 1912. These two acts have remained a model for cooperative legislation not only in pre-partition, but also in the post independence, Punjab. The major organisational and operational features of the

${ }^{1}$ See Webb, Sidney and Beatrice (1921); also see Bonner (1961). cooperation.

${ }^{2}$ See Munker (1976); also see Lambert (1963) for a detailed account of the different approaches to 
cooperative movement in the Punjab are largely derived from the ideas and value judgements that brought forth the movement in the sub-continent in 1904.

The progress of cooperatives in United Punjab may be judged by analysing performance of societies in terms of their growth and coverage granted to rural population . The total number of primary societies in the united Punjab increased from 699 (with 693 as agricultural and only 6 as non-agricultural societies) in 1910 to 23476 in 1938 (with 19057 as agricultural and 4419 as non-agricultural societies). Thus, about 81 percent of primary societies in 1938 were agricultural and only 19 percent were urban societies, indicating that cooperatives remained primarily agriculture oriented up to the end of the third decade of the present century. This position, however slightly changed in subsequent years. Thus out of a total of 27054 primary societies in 1945, some 77 percent were classified as agricultural and 23 percent as non-agricultural societies.

Nevertheless, amongst the primary agricultural societies, the cooperatives generally remained confined to the sphere of credit. Thus out of 26873 primary agricultural societies in 1945 as many as 17603 (about 66 percent) were agricultural credit societies. On the other hand, cooperatives in Punjab covered only 15 percent of the rural population in 1936-1937. Even in subsequent years this position did not change considerably. Thus in 1945, a little under 19 percent of the rural population came under the fold of this institution in Punjab.

The creation of Pakistan in 1947 in general and division of Punjab in particular affected the institution of cooperatives. The number, membership and working capital of cooperatives was suddenly cut short and the institution was worst hit at all its levels. The initial setbacks were overcome soon and cooperatives, under government patronage, were entrusted to funnel credit, improved seed, chemical fertilisers and other inputs to the farm sector. In that respect, cooperatives in Punjab have virtually acted as an instrument of the governments' agricultural policy during the past fifty years.

\section{DEVELOPMENT OF COOPERATIVES IN PAKISTAN PUNJAB}

\section{Organisational and Operational Features of Cooperatives}

There is a two tier cooperative structure in the Punjab. At the base or operational level in the villages are established primary societies. These societies, in turn are affiliated to the Punjab Cooperative Bank, organised at the provincial level. For borrowings, the Punjab Cooperative Bank mainly depends on the Federal Bank for Cooperatives. The bulk of the loans provided by the Federal Bank for Cooperatives to the Punjab Cooperative Bank are advanced for financing seasonal agricultural operations. The advances by the Punjab Cooperative Bank to the credit societies increased considerably between 1970 and 1997. The total advances made by the Punjab 
Cooperative Bank to the primary agricultural societies increased from Rs 165.13 million in 1970 to Rs 4117.39 million in 1997, with some 55 percent recovery of loans from societies during the year 1997 (see Table 1). The loans to the Punjab Cooperative Bank, for onward disbursement to the primary societies are released by the Federal Bank for Cooperatives on the approval of the State Bank of Pakistan and also on the guarantee provided by the Government of the Punjab. The Punjab Cooperative Bank, expected to operate on commercial lines, has not been successful in mobilising savings especially from the rural areas, making it difficult to supplement its own resources and with no savings of its own, it is left with a very limited role as a development bank.

Table 1

Loans Advanced and Recovered by the Punjab Cooperative Bank

\begin{tabular}{lcc} 
& & (Rs Million) \\
\hline Year & Loans Advanced & Loans Recovered \\
\hline 1970 & 165.13 & 84.48 \\
1975 & 129.60 & 22.30 \\
1980 & 883.00 & 874.00 \\
1985 & 1374.17 & 1365.52 \\
1990 & 1346.09 & 1302.82 \\
1995 & 3582.64 & 2580.01 \\
1997 & 4117.39 & 2278.69 \\
\hline
\end{tabular}

Source: (a) Government of the Punjab; Annual Reports on the working of Cooperative Societies in the Punjab (Various Issues).

(b) Haroon (1986).

(c) Chaudhry (1998).

The Federal Bank for Cooperatives was established in 1976 at the national level with the object of providing financial assistance to the provincial Cooperative Banks in all the four provinces of Pakistan. In addition, the Federal Bank for Cooperatives is entrusted the task of assisting the federal and the provincial Governments in formulating schemes for the development and revitalisation of the movement, undertake research on problems of rural credit and other matters having a bearing on the development of the cooperatives and assist the provincial Cooperative Banks in preparing their seasonal development lending programmes and undertaking appraisals as well as feasibility studies of projects covered by such programmes. However, in practice, the Federal Bank has served merely as a channel of credit catering for the credit requirements of the Punjab Cooperative Bank, as also of the other provincial Cooperative Banks. The Bank except providing loans to provincial banks, has generally failed in realising other objectives. $^{3}$

${ }^{3}$ See for instance Federal Bank for Cooperatives (1977), pp. 13-44; Government of Pakistan Report of the National Commission on Agriculture (1988), pp. 405-408. 
Primary cooperative societies have been established at the base level of the cooperative movement in the Punjab. These societies are concentrated in rural areas and with in those in the field of agricultural credit. The growth of primary societies both agricultural and non-agricultural for the years 1980 through 1997 is given in Table 2. It can be seen from Table 2, that total number of primary societies in the Punjab rose from 41533 in 1980 (with 23515 as agricultural credit and 18018 as non-agricultural credit cum urban cooperatives) to 48097 in 1997 (with 35381 as agricultural credit and 12776 as non-agricultural credit cum urban cooperatives). Thus about 73 percent of primary societies in the Punjab in 1997 were agricultural credit and only 27 percent were nonagricultural credit cum urban societies, indicating that the institution of cooperatives in the Punjab remained centred in the sphere of credit.

Table 2

Growth of Cooperatives in the Punjab at a Glance

\begin{tabular}{|c|c|c|c|c|c|c|c|c|c|}
\hline \multirow[b]{2}{*}{ Year } & \multicolumn{3}{|c|}{ No. of Cooperatives } & \multicolumn{3}{|c|}{ Membership (No.) } & \multicolumn{3}{|c|}{ Working Capital (Rs Million) } \\
\hline & Total & $\begin{array}{l}\text { Agri. } \\
\text { Credit }\end{array}$ & $\begin{array}{c}\text { All } \\
\text { Others }\end{array}$ & Total & $\begin{array}{l}\text { Agri. } \\
\text { Credit }\end{array}$ & All Others & Total & $\begin{array}{l}\text { Agri. } \\
\text { Credit }\end{array}$ & All Others \\
\hline 1980 & 41533 & 23515 & 18018 & 1652426 & 885710 & 766716 & 2433.05 & 666.07 & 1766.98 \\
\hline 1985 & 48557 & 30596 & 17961 & 2219913 & 1275251 & 944662 & 4389.76 & 895.43 & 3494.33 \\
\hline 1990 & 46197 & 33302 & 12895 & 2400532 & 1460399 & 940133 & 14393.41 & 1840.54 & 12552.87 \\
\hline 1995 & 47244 & 34669 & 12575 & 2466549 & 1615326 & 851223 & 10719.26 & 2722.70 & 799.56 \\
\hline 1997 & 48097 & 35381 & 12776 & 2510341 & 1617023 & 893318 & 12154.12 & 3358.88 & 8795.24 \\
\hline
\end{tabular}

Source: (a) Haroon (1986).

(b) Chaudhry (1998).

It is against this background that the experience of agricultural credit societies in the Punjab is now studied in detail through an examination of the following aspects.

(a) The relative importance of credit Cooperatives among institutional sources of finance.

(b) The absolute importance of cooperative credit in relation to the total credit needs of farmers.

(c) The extent of local participation in, and support for agricultural credit societies, and

(d) The welfare effects of cooperative credit distribution.

The relative importance of cooperative credit among institutional sources of finance can be judged from the data presented in Table 3. The share of cooperative credit in total institutional credit was significant during the years 1950 through 1966. This was mainly attributed to the policy of the Government in the country which showed interest in developing and expanding the role of the cooperative credit movement. Nevertheless, the provision of cooperative credit was not sufficient. The Agricultural Development Bank of Pakistan was thus established in 1961; with that the 
total supply of credit in the farm sector increased, from Rs 75.12 million in 1960 to Rs 130.49 million in 1966 or by some 174 percent. Again in 1971, all commercial Banks entered the business of rural finance. These measures enhanced the supply of farm credit, and the share of cooperative credit among the institutional sources of finance declined from around 60 percent in 1966 to about 8 percent in 1975. As against this, first the share of credit provided by the Agricultural Development Bank increased, followed by that of the commercial Banks (after 1971-72); only after 1975 did the share of cooperative credit amongst the institutional sources increased once again, however share of cooperative credit amongst institutional credit ranged between 21 and 30 percent during the years 1985-97.

Table 3

Agricultural Loans Advanced by the Institutional Sector in the Punjab

\begin{tabular}{|c|c|c|c|c|c|c|c|c|c|}
\hline \multirow[b]{2}{*}{ Year } & \multicolumn{2}{|c|}{ Cooperatives } & \multicolumn{2}{|c|}{ Taccavi Loans } & \multicolumn{2}{|c|}{ Agri. Development Bank } & \multicolumn{2}{|c|}{ Commercial Banks } & \multirow{2}{*}{$\begin{array}{l}\text { Total } \\
\text { Loan }\end{array}$} \\
\hline & Loan & \%age & Loan & \%age & Loan & \%age & Loan & \%age & \\
\hline 1950 & 82.88 & 98.33 & 1.40 & 1.67 & - & - & - & - & 84.28 \\
\hline 1955 & 31.78 & 92.4 & 2.60 & 7.5 & - & - & - & - & 34.38 \\
\hline 1960 & 69.52 & 92.5 & 5.60 & 7.4 & - & - & - & - & 75.12 \\
\hline 1966 & 78.39 & 60.0 & 3.80 & 2.9 & 48.3 & 37.1 & - & - & 130.49 \\
\hline 1970 & 99.29 & 53.2 & 3.70 & 2.1 & 77.3 & 44.6 & - & - & 173.27 \\
\hline 1975 & 81.54 & 8.0 & 12.13 & 1.2 & 396.31 & 39.2 & 52.90 & 51.5 & 1010.88 \\
\hline 1980 & 979.99 & 29.8 & 8.22 & 0.27 & 711.55 & 23.5 & 1587.40 & 52.6 & 3015.79 \\
\hline 1985 & 2110.00 & 30.5 & 4.65 & 0.06 & 2581.00 & 37.4 & 2207.00 & 32.0 & 6902.65 \\
\hline 1990 & 3034.00 & 30.5 & 7.00 & 0.06 & 6225.00 & 56.4 & 1772.00 & 16.05 & 11038.00 \\
\hline 1995 & 3302.00 & 21.58 & 13.80 & 0.09 & 10015.00 & 52.5 & 1968.00 & 12.82 & 15298.80 \\
\hline 1997 & 3725.00 & 26.29 & N.A & - & 8648.44 & 61.05 & 1792.00 & 12.65 & 14165.44 \\
\hline
\end{tabular}

Source: (a) Agricultural Statistics of Pakistan (1975).

(b) Punjab Development Statistics (1986).

(c) Punjab Development Statistics (1998).

The measures taken by the government in the late 1970s and in subsequent years resulted in increased provision of cooperative credit to the farm sector. Nevertheless, this does not imply that those who needed credit did really get it. The incentive of providing interest free loans from late 1970s until mid 1980s (later however, cooperatives advanced loans at concessional lending rates i.e. at a markup of 14-16 percent per annum) to members of societies was a good step, but unfortunately it was misused partly because it was operated through incompetent functionaries of the cooperative department, and partly through political pressure. Consequently, the advantages that were visualised at the time of conceiving these schemes were frustrated ${ }^{4}$.

${ }^{4}$ See Waheed (1985), pp. 15-18; also see Government of Pakistan Report of the National Commission on Agriculture (1988), pp. 401-402. 
The estimated total credit needs of farmers in the Punjab have never been fully met from the available supply of institutional credit. This argument obtains support from the findings of the Rural Credit Survey (1985). The survey recorded that 27 percent of all the rural households including the farm and non-farm households had some recourse to institutional credit. For the farm households this proportion was 30 percent for under 0.5 hectare category, whereas it was 44 percent for the 60 hectares and above category. On a provincial basis, the survey revealed that 34 percent of the under 0.5 hectare farmers' category in the Punjab had recourse to institutional credit, as against 65 percent of the total farm households in the Punjab. ${ }^{5}$ This shows that access to credit was generally higher amongst large sized farm holdings. These findings support the earlier view that insufficient credit was available from institutional sources and that farmers depended more on non-institutional sources to fulfil their credit needs.

Data on the working of agricultural credit societies in the Punjab are presented in Table 4. The number of credit societies increased at the rate of approximately 1 percent a year during 1960 through 1975. There was a significant increase in the formation of credit societies after 1975, as the number of societies increased from 12658 in 1975 to 23515 in 1980, showing an increase of 86 percent over the said period. This trend continued in the subsequent period. As such, the number of credit societies increased from 23515 in 1980 by about 50 percent in 1997(see Table 4). Thus the experience of the late 1970s is atypical and needs explanation. The Government of the Punjab introduced the interest-free lending policy in 1978, and used cooperatives as a vehicle to funnel interest-free credit into the farm sector. Many more credit societies in the Punjab were established under the directive of the Government. New societies were generally formed by the departmental officials without any regard to the principles of cooperation. Many societies were established overnight just to impress the superiors up the line with the successful implementation of the Government directive. As such, a policy of expansion rather than consolidation was pursued by the department from 1977 through $1980 .^{6}$ The provision of interest free credit through cooperatives was abandoned by the government during mid 1980s and emphasis was once again laid on consolidation rather than expansion of agricultural credit cooperatives during late 1980s through 1997.

${ }^{5}$ Government of Pakistan Rural Credit Survey (1985), pp. 514-19.

${ }^{6}$ The sudden increase in number of credit societies in the Punjab did not lead to the provision of sufficient credit to the subsistence farmers. Interest free loans provided by these societies were generally misutilised or misdirected to non-productive uses. For further elaboration on this point see Government of Pakistan Report of the National Commission on Agriculture (1988), pp. 399-402. 
Table 4

Lending Operations of Primary Agricultural Credit Societies in the Punjab

\begin{tabular}{rrrrrrr}
\hline Year & $\begin{array}{c}\text { No. of Credit } \\
\text { Societies }\end{array}$ & $\begin{array}{c}\text { Total } \\
\text { Membership }\end{array}$ & $\begin{array}{c}\text { Loans Advanced } \\
\text { (Rs Million) }\end{array}$ & $\begin{array}{c}\text { Loans Recovered } \\
\text { (Rs Million) }\end{array}$ & $\begin{array}{c}\text { No. of Loan } \\
\text { Beneficiaries }\end{array}$ & $\begin{array}{c}\text { Ratio of Repayment } \\
\text { to Loan Advanced }\end{array}$ \\
\hline 1954 & 8409 & 250000 & 11.44 & 10.35 & 11448 & 0.90 \\
1960 & 10822 & 396000 & 32.07 & 25.63 & 32070 & 0.79 \\
1965 & 12121 & 512000 & 34.18 & 43.08 & 34183 & 1.26 \\
1970 & 12652 & 591294 & 41.22 & 12.57 & 41220 & 0.30 \\
1975 & 12658 & 633674 & 79.88 & 28.25 & 79880 & 0.35 \\
1980 & 23515 & 885710 & 979.99 & 819.00 & 209604 & 0.83 \\
1985 & 30596 & 1275251 & 1055.71 & 1208.66 & 472923 & 1.14 \\
1990 & 33302 & 1460399 & 1346.09 & 1275.82 & 37074 & 0.94 \\
1995 & 34669 & 1615326 & 3302.70 & 3186.00 & 36570 & 0.96 \\
1997 & 35381 & 1617023 & 3725.44 & 3720.88 & 37758 & 0.99 \\
\hline Source & Gover &
\end{tabular}

Source: Government of the Punjab; Annual Reports on the Working of Cooperative Societies in the Punjab (Various Issues).

(a) Haroon (1986).

(b) Chaudhry (1998).

The Government of the Punjab made many attempts to establish large-sized viable primary units at the base level of cooperatives, but these attempts generally met little success. The underlying trend shown by the data reveal that societies generally remained small-sized. There are two reasons for such a pattern. First, the credit societies did not provide sufficient credit; the farming population found it unattractive to join cooperatives. Second, the attempts made by the department to promote the institution of cooperatives were too insignificant to persuade prospective members in rural areas to join the societies. The Rural Credit Survey of Pakistan (1975) concluded that only 4 percent of the rural households in Pakistan were enrolled in the movement. ${ }^{7}$

The Rural Credit Survey of 1985 revealed that only 1 percent of households in the smallest sized farm category reported cooperative membership but this proportion increased to 13 percent in the largest size of farm category of 60 hectares and above. The cooperative societies, according to the survey are common in the Punjab, yet only 6 percent of the total farm households reported membership. ${ }^{8}$ These statistics would imply that the institution of cooperatives in the Punjab was largely centred within bigger farm households who controlled the management of societies and imposed restrictions on the entry of new members (with small holdings), primarily to make use of Cooperatives provisions to themselves. $^{9}$

Despite the increase in the number of societies, many Cooperatives in the Punjab were regarded as economically non-viable. The Report of the National Commission on Agriculture (1988) recorded that out of 45,000 agricultural Cooperatives in Pakistan, as

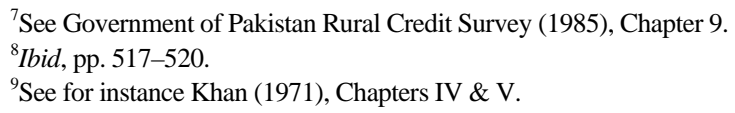

${ }^{9}$ See for instance Khan (1971), Chapters IV \& V. 
much as 50 percent were dormant, and of the remaining, probably only 5 percent were genuine, viable and active undertakings. ${ }^{10}$ According to a study conducted by the Centre for Administrative Research and Development studies in the Punjab, out of 34543 societies as many as 50 percent were found to be inactive undertakings in $1984{ }^{11}$

One way of gauging the spread of cooperative idea, to measure the extent to which farmers began to participate in the cooperatives, is to examine the quantum and composition of working capital available to societies. Total working capital available to credit societies increased from Rs 46.51 million in 1960 to Rs 143.76 million in 1975. However, there came about a manifold increase in the working capital available to the credit societies after 1975 . The working capital in societies was largely derived from the borrowings (that is loans and deposits held) rather than the share capital and reserve funds. It may be noted that during the period 1947 through 1975, the percentage share of borrowed funds (loans and deposits held) of societies ranged between 42 and 61 percent. Credit societies borrowed between 83 and 89 percent during the years 1980 through 1997 (see Table 5).

Another way of assessing the performance of credit societies was to evaluate their lending business. Total loans advanced by societies increased from Rs 11.44 million in 1954 to Rs 79.88 million in 1975. Thereafter there was a quantum jump in loans advanced by societies, which increased from Rs 979.99 million in 1980 to Rs 3725.44 million in 1997 (see Table 4). Moreover, cooperative credit, as already noted, as a share of total institutional lending increased from 8 percent in 1975 to some 26 percent in 1997 (see Table 3).

Table 5

Working Capital of Primary Agricultural Credit Societies in the Punjab

\begin{tabular}{lrrrr}
\hline Total Working & Share & (Rs Million) \\
Year & Capital & Capital & $\begin{array}{c}\text { Reserve } \\
\text { Funds }\end{array}$ & $\begin{array}{c}\text { Deposits and } \\
\text { Loans Held }\end{array}$ \\
\hline 1947 & 34.78 & 7.70 & 11.22 & 15.85 \\
1954 & 24.74 & 3.84 & 10.45 & 10.44 \\
1960 & 46.51 & 7.17 & 11.64 & 22.70 \\
1965 & 75.09 & 14.01 & 15.23 & 45.84 \\
1970 & 98.53 & 19.13 & 20.58 & 45.05 \\
1975 & 143.76 & 22.78 & 24.27 & 87.85 \\
1980 & 633.99 & 44.97 & 26.13 & 883.00 \\
1985 & 895.43 & 77.69 & 69.47 & 742.16 \\
1990 & 1840.54 & 93.88 & 191.28 & 1578.81 \\
1995 & 2722.70 & 112.97 & 231.20 & 2373.90 \\
1997 & 3358.88 & 120.07 & 243.37 & 2986.32 \\
\hline
\end{tabular}

Source: (a) Government of the Punjab; Annual Reports on the working of cooperative societies in the Punjab (Various Issues).

(b) Haroon (1986).

(c) Chaudhry (1998).

${ }^{10}$ See Government of Pakistan Report of the National Commission on Agriculture (1988), p. 401.

${ }^{11}$ See Centre for Administrative Research and Development Studies (1984), pp. 29-33. 
Relevant statistics on the lending business of societies are presented in Table 4. It may be seen that the ratio of repayment of loans advanced was not at all bad especially during 1954-65. It tended to stay fairly high. However, between 1970-75, the ratio dropped to less than 0.4; in contrast during 1975-80 ratio of repayment exceeded from less than 0.4 to a little above 0.8 . The overall average repayment to loan ratio for 195497 stayed at roughly 0.85 . And this was not at all that bad.

The higher recovery of loans by societies was (among other factors) attributed to strict adherence by the department to the administrative discipline of societies. Many defaulting members in societies were claimed to be expelled and their debts recovered as arrears of land revenue. Contrary to this argument critics ${ }^{12}$ suggest that funds meant for disbursement of loans for improved seed, chemical fertilisers and pesticides were actually diverted towards short-term interest bearing investments. And, through smart forgery new loans created in fictitious names were adjusted against the 'old' loans. Further, through this practice members in societies, besides making big illegal earnings, were able to show high recovery rates.

The data on the number of loan beneficiaries of the credit societies for the period, 1947 through 1997 were not available from departmental sources on regular basis. If it was assumed that member farmers in a society actually received the maximum loan amount prescribed, then the number of loan beneficiaries could only have been between 4 and 15 percent of the total membership during the years 1954-75. Between 1990 and 1997 the situation became rather worst, as only about 2.5 percent of the total membership could have been provided with the maximum prescribed amount of loanable funds from the societies (see Table 4). Of course, this assumption is too simplistic but it does place the amounts loaned in proper perspective. The membership of societies increased throughout 1954-97 and it is logical to expect that the members in fact received loans of a lesser share of the maximum credit limit. ${ }^{13}$

The proponents of the institution of cooperation contend that a cooperative is not supposed to be a commercial business venture or a profit making enterprise. Its objectives are largely distributional (e.g. providing welfare to its members by ensuring provision of subsidised loans). Of course, concessional lending can not be profitable in a commercial sense. Past experience suggests that concessional lending to members was a disincentive insofar as optimal productive use of cooperative credit was concerned. The large farmers and politically strong farming groups in Punjab were reported to have

\footnotetext{
${ }^{12}$ See Government of Pakistan Report of the National Commission on Agriculture (1988), Chapter 23; Khan (1982), pp. 128-29.

${ }^{13}$ Prior to 1978 , credit to cultivators was advanced on the basis of maximum credit limit (MCL). The maximum credit limit prescribed for the farmers for the irrigated and non-irrigated areas was fixed at Rs 1000 and Rs 600 respectively. The credit limit has had no relevance to either the needs of the farmer or to his repayment capacity. Similarly the MCL of a society was fixed by the central cooperative banks irrespective of the need of the credit society. It was after 1978 that MCL for a member farmer of credit societies was set at Rs 6000 per annum for the purchase of improved farm inputs. Since 1984 loans to a member in a society are advanced on per acre basis. The maximum credit limit (MCL) has been fixed Rs 5000 per acre with a markup of 14-16 percent.
} 
dominated Cooperatives and annexed government funds for their own purposes. ${ }^{14}$ It was revealed in one study that 86 percent of the committee members (as well as the large farmers) in societies were loan defaulters as against 37 percent ordinary members. ${ }^{15}$

An important task which the Department of Cooperation in the Punjab is expected to undertake is the regular audit and inspection of Cooperatives. Field studies ${ }^{16}$ undertaken in the Punjab have established that a large number of societies remain unaudited. And this in part is attributed to the shortage of trained and experienced staff in the department. Moreover, the management committee members themselves are often incompetent and often unable to record correct entries. This practice has often made it more difficult to undertake the audit task effectively. ${ }^{17}$ As a result the cooperatives have been made entirely dependent on the cooperative field staff, and have not been able to grow as an autonomous 'self-help' institution. ${ }^{18}$

\section{Effectiveness of Cooperatives as a Tool of Development}

The reports of the official Government inquiries and appraisals by independent researchers ${ }^{19}$ indicate that Cooperatives have not achieved the development goals set for them by economic planners. Even though cooperatives are sponsored by the government, their activities have little effect on the existing patterns and trends of economic activity and their performance has little relevance to the wider context of social and economic change and the general development strategy.

It was recognised that, without Governmental financial support and consequently some degree of Government control, cooperatives would have not become properly established. $^{20}$ This dependency on the Government for the establishment and support of Cooperatives has created a dilemma for the self-reliance of societies. The Cooperatives are so dependent on state assistance that it is unlikely that they would survive without Government support and replace the traditional dependency system (e.g. paternal system) by self-reliance and community initiative, achieved through cooperative action.

${ }^{14}$ See Khan (1971); Chapter V; Government of Pakistan Report of the National Commission on Agriculture (1988); Chapter 23, also see Inayatullah (1972).

${ }^{15}$ See Gill (1976), pp. 59-60.

${ }^{16}$ See for instance Khan (1971); Khan et al. (1973); Government of Pakistan Credit Inquiry Commission Report (1959); Government of Pakistan Report of the National Commission on Agriculture (1988).

${ }^{17}$ See for instance Khan (1971), pp. 83-85; Siddique (1980), pp. 31-33; Gill (1976), pp. 19-20.

${ }^{18}$ See Government of Pakistan Report of the Seminar on Integrated Rural Development (1973), pp. 92-102; Government of Pakistan Report of the Agricultural Inquiry Committee (1975), pp. 19-22; Khan (1982), pp. 120-32.

${ }^{19}$ See Government of Pakistan Report of the National Commission on Agriculture (1988); Government of Pakistan Credit Inquiry Commission Report (1959); Government of Pakistan Agricultural Inquiry Committee Report (1975); Government of the Punjab, Annual Reports on the Working of Cooperative Societies (Various Issues).

${ }^{20}$ See Chaudhry and Rizwani (1970); Chapter 3; also see Inayatullah (1972); Chapter VI. 
Overtime the Government has remained liberal in providing subsidised agricultural credit, the primary societies nevertheless often have had at their disposal only limited supplies of credit because of their failure to follow prescribed conditions, their inability to generate enough capital of their own or to recover loans. The evidence has established that much of the credit advanced by Cooperatives was not used for productive purposes.

Even productivity considerations in Cooperatives have posed a dilemma. While some cooperative members (generally members of the management and other better-off farmers in societies) took undue advantage of cooperative credit and other services, the others were not able to do so - the result-a gulf between the better-off and the ordinary members to the access of cooperative services-leading to greater economic inequalities; a practice contrary to the cooperative ideals.

The evidence has proved that there was unequal distribution of the benefits of rural Cooperatives within rural communities. Those who were already in more fortunate positions took advantage of the cooperative services; the disadvantaged of the community benefited less or not at all. Thus the Cooperatives were not effective in bringing about structural change in the communities. The impact of the community structure upon the Cooperatives was stronger than the impact of the cooperative upon the community structure. ${ }^{21}$

\section{CONCLUSIONS AND LESSONS}

It is by no means a straightforward matter to identify causes of inadequacies of institutional performance when social, political and economic considerations are woven together. The fact that the institution in question is not the product of purely local forces but has instead been transplanted from quite different time and place adds a further dimension to the complexity. Failure could be attributed to rejection of the cultural transplant due to incompatibility, or to its association with the colonial past. Alternatively, it could be due to the absence of necessary preconditions linked to opportunities for development and their perception by participants. But equally it could be attributed to government manipulation of the institution, to serve a particular and conceivably ill-suited objectives given the circumstances prevailing in agricultural input and output markets in the 20th century Punjab. Either the credit system itself needs to be changed or else the objectives should be changed so as to reduce emphasis on social goals of redistribution or relief of mass poverty and leave these goals to other kinds of programmes.

Cooperatives will not prove successful in the communities where class and caste structures are inegalitarian; cooperatives, in effect, become the preserve of the middle and upper class and their effectiveness in the community remains slight. As such cooperatives will bring success only when these are introduced into communities which have more flexible socio-economic structures. This would seem to be a principal pre-

${ }^{21}$ Ibid. 
requisite for institutional change to occur and cooperatives to be enabled to create a cohesive group oriented to local socio-economic improvements.

To be effective, however, cooperatives also need to have strong links with outside agencies, such as the secondary and apex cooperatives, and the Department of Cooperation. In spite of the risks of being interpreted as imposing an alien structure on local communities, there is still a necessity for the government to play an active role in promoting the idea of cooperation. Unless the outside agencies ensure the training of the local leaders, assist the cooperators in adopting new technology, provide sufficient credit and other requisites, audit cooperative accounts regularly and discipline those responsible for defaults and irregularities, there is no point in expecting any success from any type of cooperative.

A radical alternative to the reform of the existing cooperative institutions would be a policy seeking to evolve wholly new kinds of local organisation-'units of rural action' that could more effectively stimulate peasant participation and in particular more effectively involve the poorer members of the local community. This will however, need profound social economic and structural transformation of the rural society.

To sum up, there is a pressing need for a serious review of cooperative policy. Empirical research has established that cooperatives failure has been less a demonstration of the irrelevance of cooperative principles to the pursuit of development, and more a clear indication that the annexation of the cooperative concept to serve misguided and insensitive government policies creates organisations which are cooperatives in name only. Such a review should consider possible specific adjustments to cooperative methods and procedures to meet some of the individual problems already identified.

\section{REFERENCES}

Bonner, A. (1961) British Cooperation. Manchester: Cooperative Union.

Centre for Administrative Research and Development (1984) Agricultural Cooperative Movement in Pakistan, Perspective, Problems and Plan of Action. Lahore: CARD.

Chaudhry, H. A., and A. R. Rizwani (1970) Role of Cooperative Institutions in Planned Change in West Pakistan. Faisalabad: West Pakistan Agricultural University Press.

Chaudhry, M. A. (1998) Cooperatives in Punjab from 1990-91 to 1996-97. Lahore: Registrar Cooperatives, Government of Punjab.

Federal Bank for Cooperatives Pakistan (1977) Federal Bank for Cooperatives Act, 1977. Islamabad: FBC.

Gill, Z. A. (1976) Organisation, Functioning and Performance of Cooperatives in Rajana Markaz of Integrated Rural Development Programme. Unpublished M. Sc. Thesis, University of Agriculture, Faisalabad.

Punjab, Government of (1974, 1976, 1977, 1978, 1979, 1980, 1982) Annual Reports on the Working of Cooperative Societies in the Punjab. Supdt. Government Printing, Lahore. 
Haroon, F. (1986) Cooperatives in Punjab 1979-85. Registrar, Cooperatives, Government of Punjab, Lahore.

Inayatullah (1972) Cooperatives and Development in Asia: A Study of Cooperatives in Fourteen Rural Communities of Iran, Pakistan and Ceylon, Vol. VII. Rural Institutions and Planned Change. Geneva: UNRISD.

Khan, D. A. (1982) Delivery System in Support of Small Farmers in the Context of Rural Development-Pakistan. Centre for Integrated Rural Development for Asia and Pacific, CIRDAP, Comilla. (CIRDAP Series No. 21.)

Khan, M. A. (1971) Cooperatives Dilemma-A Study of Farm Credit Cooperatives in the Punjab. WPAU Press, Lyallpur.

Khan, M. A., D. A. Khan, and M. H. Bhatti (1973) Farm Credit Profile and Supervised Credit in Rural Pakistan. Lyallpur: University of Agriculture Press.

Lambert, P. (1963) Studies in the Social Philosophy of Cooperation. Cooperative Union Ltd, Manchester.

Munker, H. (1976) Cooperatives for the Rich or for the Poor, with Special Reference to Cooperative Development and Cooperative Law in Asia. Asian Economy 17. (June.)

Pakistan, Government of (1959) Credit Inquiry Commission Report. Government Press, Karachi.

Pakistan, Government of (1973) Report of the International Seminar on Integrated Rural Development organised jointly by Government of Pakistan, UNDP and FAO at Lahore from November 3-10. Government Press, Lahore.

Pakistan, Government of (1975) Agricultural Inquiry Committee Report. Ministry of Food and Agriculture, Islamabad.

Pakistan, Government of (1985) Pakistan Rural Credit Survey. Agricultural Census Organisation, Lahore.

Pakistan, Government of (1988) Report of the National Commission on Agriculture. Ministry of Food and Agriculture, Islamabad.

Siddique, M. (1980) Farmers' Organisations and Other Local Institutions: Cooperatives for Rural Development. Islamabad: Local Government and Rural Development Division, Government of Pakistan.

Waheed, A. (1985) The Role of Cooperatives in the Rural Development of the Punjab. Lahore: National Institute of Public Administration.

Webbs, Sidney, and Beatrice (1921) The Consumers Cooperative Movement. London: Longmans Green and Co. 